\title{
Incentives and barriers to HIV testing in men who have sex with men in a metropolitan area in Brazil
}

\author{
Incentivos e barreiras para testagem do HIV em \\ homens que fazem sexo com homens em região \\ metropolitana do Brasil
}

\author{
Incentivos y barreras para el test del VIH en \\ hombres que practican sexo con hombres \\ en una región metropolitana de Brasil
}

Valéria Freire Gonçalves 1,2

Ligia Regina Franco Sansigolo Kerr 1

Rosa Salani Mota 1

Raimunda Hermelinda Maia Macena 1

Rosa Lívia de Almeida 1

Deborah Gurgel Freire 1

Ana Maria de Brito ${ }^{3}$

Inês Dourado 4

Laëtitia Atlani-Duault 5

Laurent Vidal 6

Carl Kendall 7

\begin{abstract}
This study aimed to identify incentives and barriers to HIV testing in men who have sex with men (MSM). This was a cross-sectional study of MSM who had lived at least three months in greater metropolitan Fortaleza, Ceará State, Brazil, 2010. The study recruited 391 men $\geq 18$ years of age who reported sexual relations with men in the previous six months, using Respondent Driven Sampling. Personal network and socio-demographic data were collected and HIV testing was offered, analyzed with RDSAT 6.0 and Stata 11.0. The majority were young (40.3\%), had 5 to 11 years of schooling (57.3\%), were single (85.1\%), had low income (37.6\%), and $58.1 \%$ had tested for HIV some time in life. Incentive to test: certainty of not being infected (34.1\%) and the exposure to national campaign Fique Sabendo [Know your Status] (34\%). Barriers: trust in partner(s) (21\%) and fear of discrimination if tested positive (20.3\%). Policies should be developed to ensure test confidentiality and communication campaigns focusing on information gaps and encouragement for testing.
\end{abstract}

HIV; Anonymous Testing; Male Homosexuality; Sexual Behavior

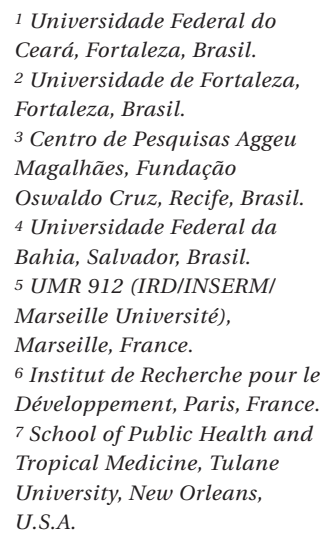

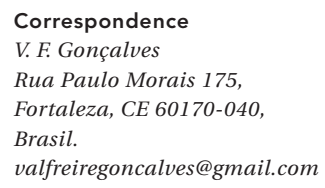




\section{Introduction}

The AIDS epidemic in Brazil is concentrated among the most vulnerable groups, including men who have sex with men (MSM). MSM have the highest HIV prevalence of any population group in Brazil (14\%) ranging from 5 to $24 \%$ in different regions of the country 1 . This represents a rate 13 times higher than that of heterosexual men 1,2,3. Moreover, $29 \%$ of reported AIDS cases in the country occur among MSM, with nearly $40 \%$ in young adults (15 and 24 years) 1,2 . Among the reasons commonly ascribed are risky sex, the difficulty of access to services and resources for diagnosis and treatment 1 .

The objectives of second generation surveillance are to better understand the dynamics of the epidemic and to improve outcomes through early identification 4,5 . A study conducted in six cities in the United States with MSM, aged 1529 years revealed that $10 \%$ were HIV-positive, however, $77 \%$ did not know their HIV status, and among blacks this percentage rose to $91 \% 6$. In Brazil, rates of lifetime testing among MSM were $49 \%$, which is considered low, especially for this population 1 .

Testing for HIV is the main tool for the early diagnosis of HIV infection and has the potential to contribute significantly to reducing transmission rates, morbidity and mortality. The benefits of treatment with antiretrovirals for the individual and community are much greater if started early 7 . For MSM in a monogamous relationship testing for HIV is recommended at least once a year 6,8,9.

In Brazil, the current public policy is to expand access to HIV testing through Primary Care Units, Counseling and Testing Centers (ATC) and through promoting voluntary testing in the Fique Sabendo [Know your Status] campaign $10,11,12$, but these strategies are still at an incipient stage.

The AIDS epidemic is distributed very unevenly in the five regions of Brazil. Although incidence rates have been considered moderate in the Southeast and Central, in the South, North and Northeast, HIV prevalence continues to increase 10,13. The northeast concentrates the highest rates of poverty and lowest levels of education in Brazil. The region presents the worst indicators for prevention and, at the same time, highest rates of risk factors for HIV infection, such as a higher percentage of unprotected sex, little routine HIV testing and difficult access to health services. Surveillance of the epidemic in this area of the country, especially among the most vulnerable groups, and knowledge of the causes of low rates of testing is a priority 3 .
The aim of this study was to identify incentives and barriers to HIV testing among MSM in the Fortaleza Metropolitan Region, Ceará State, Brazil.

\section{Methods}

\section{Study population}

We conducted a cross-sectional study with MSM in Fortaleza, between October and November 2010. The study utilized Respondent Driven Sampling (RDS) to recruit the sample. RDS, a chainlink sampling method used for HIV biological and behavioral surveillance around the world has been used successfully in Fortaleza and has been demonstrated to be more effective at recruiting respondents of lower socioeconomic status than Time Location Sampling, the only alternative $14,15,16$. RDS begins with members of the target community ("seeds"), selected by the researchers; they in turn recruit a limited number of community members who continue the recruitment process. RDS is well enough known that a set of STROBE guidelines have been published specifying best practices 17 . Chains of recruiters and recruits are linked with uniquely numbered coupons which permit tracking of chains, assure recruitment and eligibility and reduce masking $14,16,18,19$. To encourage participation and cover costs to participate in the survey, recruiters and recruits receive a financial incentive. Surveillance requires active community support and this study was conducted with the support of the Support Group for the Prevention of AIDS (GAPA/CE) and Asa Branca Resistance Group (GRAB), both non-governmental organizations with lengthy experience in the field of HIV/AIDS representing MSM. The study was conducted at two public health centers: one was a Voluntary Counseling and Testing (VCT) center located in a poor neighborhood open during business hour and the other one was a Public Health Center located in a higher social class neighborhood open in the evenings.

Formative research, consisting of five expert interviews and 10 in-depth interviews with community members, was conducted. Topics included study logistics, level of incentive, materials to be distributed at the sites and interest in the study. Two cell phone numbers were available to make appointments, but most participants presented spontaneously at the sites. The seeds were selected from among the different social classes utilizing the Brazil Economic Classification Criteria (CCEB). The study began with six seeds of diverse ages and no additional 
seeds were required. Each seed and subsequent recruiter received three coupons to distribute. Participants needed to meet eligibility requirements: having had sex with a man in the last six months; not having participated in the study previously; being aged 18 or older; residing in Fortaleza for at least three months; presenting a valid coupon; being willing to respond to the questionnaire; being willing to sign the consent form; and not obviously under the influence of drugs or alcohol.

The working team consisted of a supervisor, four interviewers, two counselors and a nurse. The face-to-face interview was recorded on pocket PCs. Upon completion, participants were offered a rapid HIV test with pre and post-test counseling. The rapid test followed the existing national algorithm at that time: first, the Rapid Check HIV-1 and 2 (Federal University of Espírito Santo, Vitória, Brazil) and Bio-Manguinhos HIV 1 and 2 (Oswaldo Cruz Foundation, Rio de Janeiro, Brazil) administered simultaneously. An option existed for a third test if results differed, but no such incident occurred during the study. Positive cases were provided special referral for treatment. Participants received BRL 15 ( USD 9) for transportation and for their time and an additional BRL 15 for each eligible recruit entered into the study.

\section{Data collection}

Data were collected using a structured questionnaire that contained the following groups of variables: eligibility (confirmation of eligibility for participation in the study and their social network in relation to MSM), participants' personal social network sizes (measured by a cascade of questions that arrived at a number of MSM, who were 18 or older, with whom they were familiar, met or talked to in the two previous months, and who they might invite to participate in this study), sexual behavior (sexual history, number and types of sexual partners), socio-demographic information (age, education, socioeconomic status, race and ethnicity, marital status, current residence, and individual and family income), HIV testing (ever tested, last time and how many times tested, incentives and barriers to testing, advantages of testing and opinion relating to HIV testing).

\section{Data analysis}

We estimated the crude and adjusted prevalence of variables of interest for the study as well as the confidence interval of $95 \%$ using version 6.0 of the Respondent Driven Sampling Analysis Tool -
RDSAT (http:/ /www.respondentdrivensampling. org/). Parameters were set to 15,000 re-sampling, a $95 \%$ confidence interval (alpha $=0.025$ ), and the other options set to default. The individual weights were calculated for the variable "testing" and then transferred to Stata, version 12.0 (StataCorp LP, College Station, USA), for further analysis. Graphs were generated with NetDraw 2.3.1 (Analytic Technologies, Lexington, USA).

\section{Ethical considerations}

Personal identifiers beyond age were not collected in the study. However, a record of the receipt of incentives was required by the donor. These receipts were included in documentation provided to the donor, but never associated with the study ID number. Consent forms were signed by the interviewer confirming their voluntary participation. In compliance with the regulations governing research with human beings, Resolution n. 196 of the Brazilian National Health Council (CNS), the study was submitted to the Ethics Research Committee of the Federal University of Ceará and approved under protocol 263/09.

\section{Results}

The study recruited 391 MSM. The six seeds generated 13 waves. Two seeds recruited $89.3 \%$ of the sample, with one very large component. The average number of persons per wave was 29 (range: 8-43, SD = 11.6) (Figure 1).

Participants ranged in age from 18 to 59 years (mean $=26.7, \mathrm{SD}=9.2$ ), with the largest single group between $18-20$ years $(40.3 \%)$. More than $1 / 3$ reported $9-11$ years of education $(37.4 \%$, mean $=11, \mathrm{SD}=3$ ), more than half belonged to the middle socioeconomic class (C; 57.6\%), most self-reported as "moreno"/mulatto/brown (66.5\%), single $(85.1 \%)$, living with mother and/ or father (53.4\%) (Table 1).

The majority (97.6\%) reported at least one advantage to HIV testing. Key benefits cited were: knowledge of status (91.3\%), starting treatment early if infected (83.5\%), to take better care of one's health $(70.1 \%)$, to protect partner or partners $(59.9 \%)$, to avoid diseases that come with AIDS (56.7\%), to have sex without fear (55.6\%), increase the quality of survival with HIV (54.1\%), to serve as a warning for people to take better care of themselves (48.5\%). A large majority responded that all people should be tested $(89.3 \%)$, that testing should be periodic $(70.4 \%)$ and over half $(54.1 \%)$ responded that gays and MSM should be tested more than the general population (Table 2). 

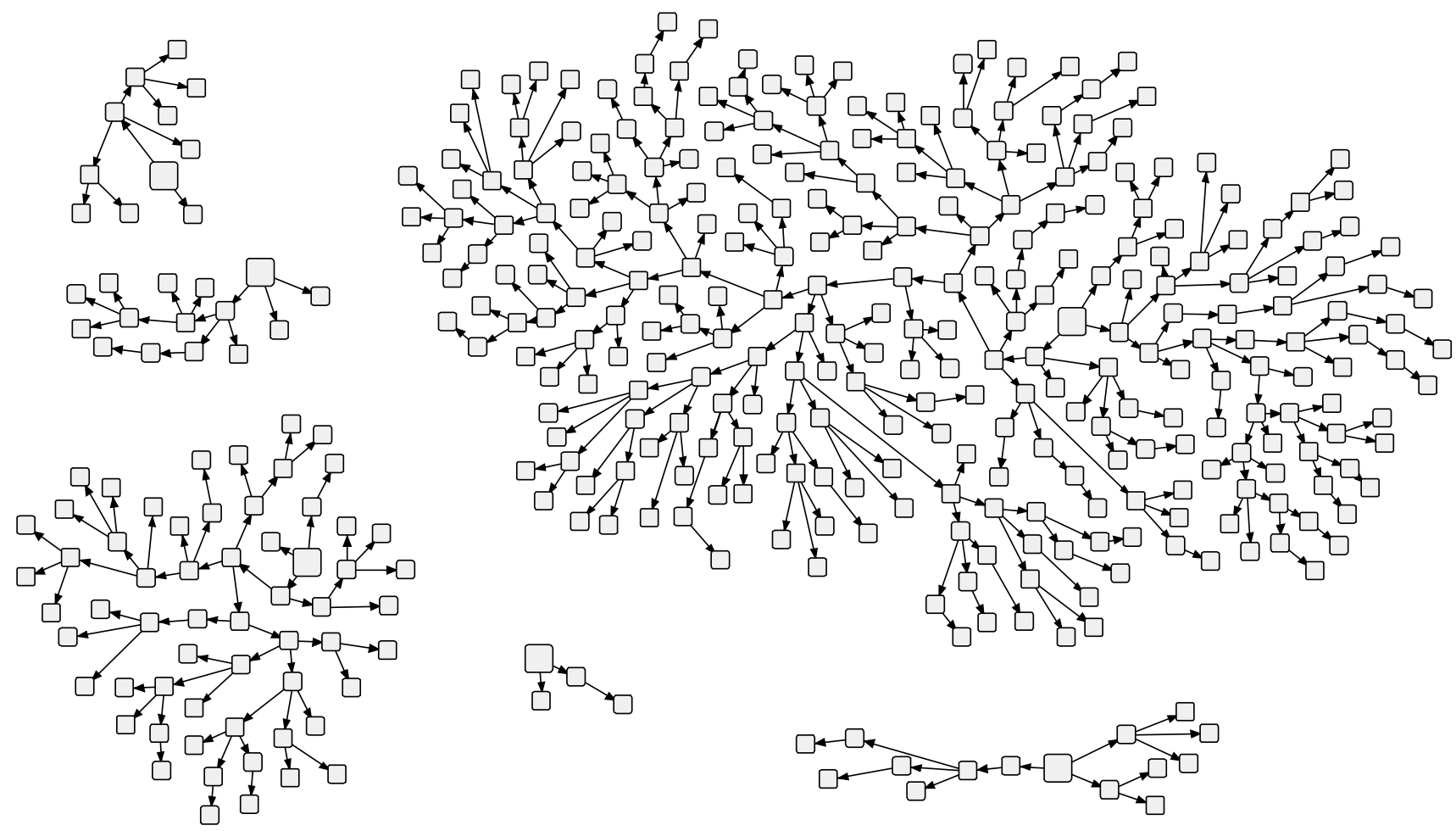

Although knowledge and attitudes towards testing were extremely positive, self-report of testing was less enthusiastic. Less than two thirds of the sample $(58.1 \%)$ reported having ever tested for HIV and $64.8 \%$ of them (or only $37.7 \%$ of the total) tested in the last year. For respondents who had tested with the rapid test $(26.9 \%)$, the most frequently cited reasons for testing was knowledge of serostatus $(34.1 \%)$, response to the national campaign Fique Sabendo (34\%), to check when their partner has other partners $(28.9 \%)$ and ease of access to testing facilities (27.1\%) (Table 3). Also mentioned: recommended by a health professional, knowing that AIDS is treatable, having several partners, and being at high risk (Table 3).

Forty-two percent (42\%) reported never testing for HIV. Reasons provided included: believing in the trustworthiness of their partner (21\%), fear of suffering discrimination if the result is positive (20.3\%), believing that there is no risk of becoming infected (20\%), unaware of a testing site $(11.3 \%)$, having a steady partner $(7.6 \%)$, not having time to go to the unit (7.2\%), and fear of breach of confidentiality by health professionals (7\%) (Table 3).

Most participants (81.9\%) tested for HIV during the study and $4.2 \%$ were positive for HIV. Of those infected, $75 \%$ reported that the main reasons for testing were: the Fique Sabendo campaign $(19.8 \%)$; sure that their partner has other partners $(9.9 \%)$; knows that AIDS is treatable $(11.7 \%)$ and having had sex without a condom (17.1\%) (data not displayed).

\section{Discussion}

MSM are among the most vulnerable populations for HIV in high- and middle-income countries including Brazil, and testing is recommended annually or more frequently 8,9,20,21,22. However, this recommended level of testing is almost never found and the percentage of participants who ever tested in our sample was relatively low. The results presented here are somewhat higher 
Table 1

Socioeconomic characteristics of men who have sex with men (MSM). Fortaleza, Ceará State, Brazil, 2010.

\begin{tabular}{|c|c|c|c|c|}
\hline Variables & Observed (n) & Crude (\%) & Estimated (\%) * & $95 \% \mathrm{Cl}$ \\
\hline \multicolumn{5}{|l|}{ Age (years) } \\
\hline 18|--|20 & 128 & 32.7 & 40.3 & $32.5 ; 48.9$ \\
\hline $21|--| 25$ & 97 & 24.8 & 26.5 & $20.1 ; 33.3$ \\
\hline $26|--| 30$ & 62 & 15.9 & 12.0 & $8.1 ; 17.1$ \\
\hline $31|--| 40$ & 62 & 15.9 & 12.7 & $8.1 ; 16.7$ \\
\hline $41 \mid--59$ & 42 & 10.7 & 8.6 & $4.1 ; 13.4$ \\
\hline \multicolumn{5}{|l|}{ Years of schooling } \\
\hline$<4$ & 14 & 3.6 & 3.7 & $1.3 ; 6.7$ \\
\hline $5|--| 8$ & 64 & 16.4 & 19.9 & $14.0 ; 25.0$ \\
\hline 9|--|11 & 136 & 34.8 & 37.4 & $31.0 ; 44.5$ \\
\hline $12|--| 13$ & 102 & 26.1 & 18.4 & $13.7 ; 24.0$ \\
\hline$>14$ & 49 & 12.5 & 11.6 & $7.5 ; 16.2$ \\
\hline Did not answer & 26 & 6.6 & 9.1 & $4.9 ; 13.7$ \\
\hline \multicolumn{5}{|l|}{ Economic class } \\
\hline$A / B$ & 57 & 14.6 & 11.8 & $8.0 ; 16.6$ \\
\hline$C$ & 247 & 63.2 & 57.6 & $50.8 ; 65.1$ \\
\hline $\mathrm{D} / \mathrm{E}$ & 74 & 18.9 & 24.5 & $17.8 ; 31.3$ \\
\hline Missing & 13 & 3.3 & 6.1 & $2.3 ; 10.0$ \\
\hline \multicolumn{5}{|l|}{ Race } \\
\hline White & 80 & 20.5 & 21.3 & $15.8 ; 26.9$ \\
\hline Black & 25 & 6.4 & 7.5 & $3.9 ; 11.7$ \\
\hline Asian & 18 & 4.6 & 4.2 & $1.6 ; 7.4$ \\
\hline Mulatto & 267 & 68.3 & 66.5 & $60.1 ; 73.1$ \\
\hline Do not know & 1 & 0.3 & 0.5 & $0.0 ; 1.7$ \\
\hline \multicolumn{5}{|l|}{ Civil status } \\
\hline Married & 8 & 2.0 & 2.1 & $0.3 ; 4.7$ \\
\hline Single & 329 & 84.1 & 85.1 & $80.2 ; 90.0$ \\
\hline Living with same gender & 40 & 10.2 & 9.2 & $5.5 ; 13.3$ \\
\hline Living with a female & 7 & 1.8 & 3.0 & $0.7 ; 5.9$ \\
\hline Divorced & 7 & 1.8 & 0.6 & $0.2 ; 1.2$ \\
\hline \multicolumn{5}{|l|}{ Currently living } \\
\hline Alone & 27 & 6.9 & 4.5 & $2.5 ; 6.7$ \\
\hline With male & 50 & 12.8 & 11.3 & $7.3 ; 16.0$ \\
\hline With female & 9 & 2.3 & 3.9 & $1.3 ; 7.4$ \\
\hline Friends & 18 & 4.6 & 4.5 & $2.4 ; 7.8$ \\
\hline Parents & 214 & 54.7 & 53.4 & $45.1 ; 60.0$ \\
\hline Other relatives & 61 & 15.6 & 18.4 & $13.2 ; 23.8$ \\
\hline Other & 12 & 3.1 & 4.1 & $1.6 ; 7.9$ \\
\hline \multicolumn{5}{|c|}{ Monthly income (minimum wages) } \\
\hline No income & 83 & 21.2 & 21.1 & $15.4 ; 27.0$ \\
\hline $0--\mid 1$ & 149 & 38.1 & 37.6 & $31.4 ; 44.6$ \\
\hline $1--\mid 2$ & 90 & 23.0 & 21.5 & $15.2 ; 26.8$ \\
\hline $2--\mid 3$ & 26 & 6.6 & 6.0 & $3.1 ; 10.4$ \\
\hline$>3$ & 43 & 11.0 & 13.7 & $8.9 ; 19.2$ \\
\hline \multicolumn{5}{|c|}{ Family income (minimum wages) } \\
\hline$<1$ & 51 & 13.0 & 14.0 & $9.5 ; 19.3$ \\
\hline $1--\mid 2$ & 91 & 23.3 & 24.3 & $17.9 ; 30.4$ \\
\hline $2--\mid 3$ & 74 & 18.9 & 16.5 & $11.9 ; 21.3$ \\
\hline$>3$ & 139 & 35.5 & 38.3 & $32.0 ; 45.9$ \\
\hline Don't know & 36 & 9.2 & 6.8 & $4.4 ; 9.6$ \\
\hline
\end{tabular}

$95 \% \mathrm{Cl}: 95 \%$ confidence interval.

* Values adjusted with RDSAT 6.0. 
Main incentives reported by men who have sex with men (MSM) to test for HIV among those reporting incentives. Fortaleza, Ceará State, Brazil, 2010.

\begin{tabular}{|c|c|c|c|c|}
\hline Variables & Observed (n) & Crude (\%) & Estimated (\%) * & $95 \% \mathrm{Cl}$ \\
\hline \multicolumn{5}{|l|}{ Reporting any incentive to test } \\
\hline Yes & 382 & 100.0 & 97.6 & $94.6 ; 99.7$ \\
\hline \multicolumn{5}{|l|}{ Reported incentives ( $\mathrm{n}=382$ ) } \\
\hline To know if he is infected & 338 & 88.5 & 91.3 & $87.8 ; 94.2$ \\
\hline Access to early treatment if infected & 317 & 83.0 & 83.5 & $78.8 ; 88.4$ \\
\hline To take care better of the body and health & 253 & 66.2 & 70.1 & $64.8 ; 76.2$ \\
\hline Protect the partners & 218 & 57.1 & 59.9 & $53.0 ; 66.7$ \\
\hline To be safe to have sex without fear & 192 & 50.3 & 55.6 & $48.8 ; 62.5$ \\
\hline Avoid opportunistic AIDS disease & 207 & 54.2 & 56.7 & $49.0 ; 3.5$ \\
\hline Increase survival and quality of life & 189 & 49.5 & 54.1 & $47.2 ; 61.3$ \\
\hline Warning people to start taking care of their health & 160 & 41.9 & 48.5 & $41.6 ; 55.5$ \\
\hline Ending a relationship if test result positive & 80 & 20.9 & 22.0 & $16.9 ; 28.0$ \\
\hline To have sex with no condom & 37 & 9.7 & 8.5 & $5.3 ; 11.9$ \\
\hline \multicolumn{5}{|l|}{ Opinion concerning HIV test } \\
\hline Everybody should test more & 345 & 90.3 & 89.3 & $84.3 ; 93.2$ \\
\hline The test protects both during sex & 283 & 74.1 & 74.7 & $69.1 ; 80.3$ \\
\hline It is important to test regularly & 253 & 66.2 & 70.4 & $64.7 ; 76.5$ \\
\hline Every time you have risky sexual behavior you should test & 219 & 57.3 & 57.6 & $52.3 ; 65.0$ \\
\hline MSM should test more than general population & 198 & 51.8 & 54.1 & $48.0 ; 61.2$ \\
\hline Always using a condom makes me comfortable to not test & 99 & 25.9 & 25.5 & $19.8 ; 31.3$ \\
\hline
\end{tabular}

95\% Cl: 95\% confidence interval.

* Values adjusted with RDSAT 6.0.

than the results found in a national survey in ten Brazilian cities, where $49 \%$ of gay men and other MSM reported ever testing for HIV 1 . However, these results, especially for those who reported being tested in the last year (38\%), are much lower than those found for MSM in other developed countries where $67 \%$ to $92 \%$ reported testing in the last year 23,24. Different from the proportion of MSM in our study who tested, the prevalence of HIV among the participants in our study was lower than the national prevalence but similar to other metropolitan areas in the northeast 1 .

At the same time, most participants tested during this study, and it can be argued that many that did not test refused because they had recently been tested. How to reconcile this testing with low levels of routine testing? One dimension could certainly relate to lack of faith in the confidentiality of testing in routine services, and consequent fear of discrimination. Discrimination and stigma are well known barriers to testing 1,8,23,25,26,27,28,29. Respondents also reported low levels of risk. Low perceived risk would provide little motivation to find out about testing locations and hours of operation. Motivation appears to be provided through public campaigns, and some men pointed to the Fique Sabendo campaign as a reason for testing, but exposure and response to campaign messages was relatively low. Men in stable, long-term relationships might also feel at low risk. If deciding not to test is considered a demonstration of faith in your partner and a loving relationship, testing would be less likely to be considered routine and appropriate ${ }^{30}$. Personal self-negotiation concerning risk and testing may also be manifest in the finding that respondents recommend regular and routine testing for others, even if they themselves do not test. These elements might be integrated into future campaigns to encourage early and routine testing 25 .

This study shows that fewer than half of the respondents reported never having tested. Epidemiological evidence for early detection and treatment is promising, and routine testing enables early diagnosis and treatment of infection and may reduce disease transmission 8,20,31,32. Added to these advantages, knowledge of HIV serostatus reduces risky behavior and thereby reduces transmission of the virus 25,33.

This study employed RDS, a method recommended by both the Centers for Disease Control 
HIV testing, incentives and barriers to test among men who have sex with men (MSM) who tested. Fortaleza, Ceará State, Brazil, 2010.

\begin{tabular}{|c|c|c|c|c|}
\hline Variables & Observed (n) & Crude (\%) & Estimated (\%) * & $95 \% \mathrm{Cl}$ \\
\hline \multicolumn{5}{|l|}{ Ever tested (lifetime) } \\
\hline Yes & 254 & 65.0 & 58.1 & $50.5 ; 65.0$ \\
\hline No & 137 & 35.0 & 41.9 & $35.0 ; 49.5$ \\
\hline \multicolumn{5}{|l|}{ When was the last time you tested? $(n=254)$} \\
\hline Less than 3 months & 48 & 18.9 & 12.8 & $7.7 ; 20.7$ \\
\hline Between 4 and 6 months & 64 & 25.2 & 28.9 & $17.8 ; 36.3$ \\
\hline Between 7 and 11 months & 63 & 24.8 & 23.2 & $16.1 ; 33.8$ \\
\hline Between 1 and 5 years & 52 & 20.5 & 25.3 & $15.1 ; 33.7$ \\
\hline More than 5 years ago & 25 & 9.8 & 9.2 & $4.6 ; 17.6$ \\
\hline Do not know or do not remember & 2 & 0.8 & 0.7 & $0.0 ; 2.5$ \\
\hline \multicolumn{5}{|l|}{ Incentives } \\
\hline \multicolumn{5}{|l|}{ Principal reasons to test $(n=105) * \star$} \\
\hline To be certain not infected & 12 & 11.4 & 34.1 & $9.3 ; 57.0$ \\
\hline Fique Sabendo campaign & 40 & 38.1 & 34.0 & $10.7 ; 39.1$ \\
\hline Sure that their partner has other partners & 21 & 20.0 & 28.9 & $9.1 ; 41.1$ \\
\hline Easy access to a health service & 26 & 24.8 & 27.1 & $8.3 ; 34.4$ \\
\hline Treatment available & 16 & 15.2 & 23.6 & $6.4 ; 35.3$ \\
\hline Have many partners & 10 & 9.5 & 23.4 & $4.8 ; 39.7$ \\
\hline Exposed to risk & 18 & 17.1 & 23.3 & $8.2 ; 47.1$ \\
\hline Health professional encouraged me to test & 16 & 15.2 & 23.2 & $8.9 ; 37.2$ \\
\hline Do not trust my partner & 18 & 17.1 & 16.1 & $3.6 ; 22.8$ \\
\hline Have sex without condoms & 10 & 9.5 & 11.5 & $2.3 ; 27.3$ \\
\hline Needle stick & 3 & 2.9 & 7.2 & $\star \star \star$ \\
\hline Refuse to respond & 1 & 1.0 & - & - \\
\hline \multicolumn{5}{|l|}{ Barriers } \\
\hline \multicolumn{5}{|l|}{ Principal reasons for not testing $(n=137)$} \\
\hline Believe in partner & 24 & 17.5 & 21.0 & $4.2 ; 37.8$ \\
\hline Fear of discrimination if positive result & 40 & 29.2 & 20.3 & $9.6 ; 36.7$ \\
\hline Believe at low risk & 24 & 17.5 & 20.0 & $6.1 ; 35.3$ \\
\hline Do not know where to test & 22 & 16.1 & 11.3 & $2.8 ; 19.9$ \\
\hline Have a stable partner & 10 & 7.3 & 7.6 & $0.0 ; 14.9$ \\
\hline Cannot attend clinic when it is open (difficult access) & 11 & 8.0 & 7.2 & $0.0 ; 10.9$ \\
\hline Fear of confidentiality of results & 17 & 12.4 & 7.0 & $0.0 ; 14.8$ \\
\hline
\end{tabular}

95\% Cl: 95\% confidence interval.

* Values adjusted with RDSAT 6.0;

** Multiple responses allowed;

*** $\mathrm{n}$ too small to calculate.

and Prevention (CDC) and by the Brazilian National STD/AIDS and Viral Hepatitis program 34. Some controversy surrounds the claim that RDS generates a probability sample, and around other assumptions of RDS and the interpretation of data. However, the method suits public health surveillance better than snowball sampling or Time Location Sampling in Fortaleza, as demonstrated in studies with vulnerable populations previously conducted here 14 .
In conclusion, in spite of recommendations that routine HIV testing is a public health strategy in the prevention and early diagnosis of HIV/ AIDS, several factors and consistent barriers to testing are found among this MSM population. It appears that government media campaigns can influence testing, and were cited as a motivating factor by respondents. Barriers, related to the fear of positive serostatus, the stigma still associated with HIV, coupled with concern about confiden- 
tiality in health services, among the variables studied here, appear to account for low levels of routine testing.

Policies to assure confidentiality of testing, and public communication campaigns addressing gaps in knowledge related to barriers and advocating testing need to be developed. Our study suggests that these campaigns be targeted to MSM, focusing on the importance of knowing one's serostatus for early treatment, sex without fear, and protecting one's partner. It also suggests that policies need to be changed to encourage regular and routine testing with a number of new technologies and in a wider range of venues. These could include better use of NGOs and home testing.

\section{Contributors}

V. F. Gonçalves contributed to the fieldwork, data collection, tabulation and data analysis, and manuscript preparation. L. R. F. S. Kerr and C. Kendall designed the study, and contributed to interpretation, data analysis, and manuscript preparation. R. S. Mota contributed to the interpretation and data analysis and manuscript preparation. R. H. M. Macena contributed to the fieldwork, interpretation, data analysis, and manuscript preparation. R. L. Almeida contributed to the interpretation and data analysis. D. G. Freire, A. M. Brito and I. Dourado contributed to the interpretation and data analysis and reviewed the paper. L. Atlani-Duault and L. Vidal reviewed the paper.

\section{Acknowledgments}

We thank the participants for making possible this research.

\section{References}

1. Kerr LR, Mota RS, Kendall C, Pinho AD, Mello MB, Guimarães MD, et al. HIV among MSM in Brazil. AIDS 2013; 27:427-35.

2. Ministério da Saúde. Boletim Epidemiológico de AIDS/DST 2011; 8(1).

3. Barbosa Júnior A, Szwarcwald CL, Pascom ARP, Souza Júnior PB. Tendências da epidemia de AIDS entre subgrupos sob maior risco no Brasil, 19802004. Cad Saúde Pública 2009; 25:727-37.

4. Brasil. Metas e compromissos assumidos pelos Estados-Membros na Sessão Especial da Assembleia Geral das Nações Unidas sobre HIV/Aids. Brasília: Ministério da Saúde; 2010.

5. Ministério da Saúde. Plano nacional de enfrentamento da epidemia de Aids e das DST entre gays, HSH e travestis. Brasília: Ministério da Saúde; 2010.

6. MacKellar DA, Valleroy LA, Secura GM, Behel S, Bingham T, Celentano DD, et al. Unrecognized HIV infection, risk behaviors, and perceptions of risk among young men who have sex with men: opportunities for advancing HIV prevention in the third decade of HIV/AIDS. J Acquir Immune Defic Syndr 2005; 38:603-14.

7. Cambiano V, Rodger AJ, Phillips AN. 'Test-andtreat': the end of the HIV epidemic? Curr Opin Infect Dis 2011; 24:19-26.

8. Johnson AS, Heitgerd J, Koenig L, van Handel M, Branson BM, Connelly E, et al. Vital signs: HIV testing and diagnosis among adults, United States, 2001-2009. MMWR Morb Mortal Wkly Rep 2010; 59:1550-5. 
9. Bayer R, Fairchild AL. Changing the paradigm for HIV testing: the end of exceptionalism. N Engl J Med 2006; 355:647-9.

10. Pinto ACS, Pinheiro PNC, Vieira NFC, Alves MDS. Compreensão da pandemia da AIDS nos últimos 25 Anos. DST J Bras Doenças Sex Transm 2007; 19:45-50.

11. Paiva V, Pupo LR, Barboza R. O direito à prevenção e os desafios da redução da vulnerabilidade ao HIV no Brasil. Rev Saúde Pública 2006; 40 Suppl:109-19.

12. Programa Nacional de DST e AIDS, Ministério da Saúde. Centros de Testagem e Aconselhamento do Brasil: desafios para a equidade e o acesso. Brasília: Ministério da Saúde; 2008.

13. Secretaria de Vigilância em Saúde, Ministério da Saúde. Doenças infecciosas e parasitárias: guia de bolso. 8a Ed. Brasília: Ministério da Saúde; 2010.

14. Kendall C, Kerr LR, Gondim RC, Werneck GL, Macena RH, Pontes MK, et al. An empirical comparison of respondent-driven sampling, time location sampling, and snowball sampling for behavioral surveillance in men who have sex with men, Fortaleza, Brazil. AIDS Behav 2008; 12 (4 Suppl):S97-104.

15. Heckathorn DD. Respondent-driven sampling II: deriving valid population estimates from chainreferral samples of hidden populations. Soc Probl 2002; 49:11-34.

16. Johnston L, Sabin K. Sampling hard-to-reach populations with respondent driven sampling. Methodological Innovations Online 2010; 5:38-48.

17. White RG, Hakim AJ, Salganik MJ, Spiller MW, Johnston LG, Kerr LR, et al. Strengthening the reporting of observational studies in epidemiology for respondent-driven sampling studies: 'STROBERDS' statement. J Clin Epidemiol 2015; 68:1463-71

18. Heckathorn DD. Respondent-driven sampling: a new approach to the study of hidden populations. Soc Probl 1997; 44:174-99.

19. Salganik MJ, Heckathorn DD. Sampling and estimation in hidden populations using respondent driven sampling. Sociol Methodol 2004; 34: 193-240.

20. Cassell MM, Surdo A. Testing the limits of case finding for HIV prevention. Lancet Infect Dis 2007; 7:491-5.

21. Lo Y-C, Turabelidze G, Lin M, Friedberg Y. Prevalence and determinants of recent HIV testing among sexually active men who have sex with men in the St. Louis Metropolitan Area, Missouri, 2008. Sex Transm Dis 2012; 39:306-11.

22. Branson BM, Handsfield HH, Lampe MA, Janssen RS, Taylor AW, Lyss SB, et al. Revised recommendations for HIV testing of adults, adolescents, and pregnant women in health-care settings. Atlanta: Centers for Disease Control and Prevention; 2006.

23. Desai M, Desai S, Sullivan AK, Mohabeer M, Mercey D, Kingston MA, et al. Audit of HIV testing frequency and behavioural interventions for men who have sex with men: policy and practice in sexual health clinics in England. Sex Transm Infect 2013; 89:404-8.
24. Tseng F-C, Ko N-Y, Lee H-C, Wu C-J, Hung C-C, Ko W-C. HIV risk profiles differed by gender and experience of men who had sex with men among attendees of anonymous voluntary counseling and testing in Taiwan. AIDS Care 2013; 25:1092-101.

25. Dowson L, Kober C, Perry N, Fisher M, Richardson D. Why some MSM present late for HIV testing: a qualitative analysis. AIDS Care 2012; 24:204-9.

26. França Junior I, Calazans G, Zucchi EM. Changes in HIV testing in Brazil between 1998 and 2005. Rev Saúde Pública 2008; 42:84-97.

27. Carvalho C. Acesso, práticas e barreiras ao teste VIH. Arq Med 2009; 23:68-9.

28. de Olalla PG, Mazardo C, Sambeat MA, Ocaña I, Knobel H, Humet V, et al. Epidemiological characteristics and predictors of late presentation of HIV infection in Barcelona (Spain) during the period 2001-2009. AIDS Res Ther 2011; 8:22.

29. MacKellar DA, Hou SI, Whalen CC, Samuelsen K, Sanchez T, Smith A, et al. Reasons for not HIV testing, testing intentions, and potential use of an over-the-counter rapid HIV test in an internet sample of men who have sex with men who have never tested for HIV. Sex Transm Dis 2011; 38: 419-28.

30. Kendall C. The construction of risk in AIDS control programs: theoretical bases and popular responses. In: Parker RG, Gagnon JH, editors. Conceiving sexuality: approaches to sex research in a postmodern world. New York: Routledge; 1995. p. 249-58.

31. Kerr LR, Mota RS, Kendall C. Epidemiologia do HIV/aids entre homens que fazem sexo com homens (HSH) no Brasil. In: Castro C, Pedrosa F, organizadores. Rede SAGAS Brasil: interações preventivas com juventudes homossexuais, mulheres lésbicas e pessoas vivendo com HIV/AIDS. Fortaleza: Grupo de Resistência Asa Branca; 2012. p. 99-122.

32. Jaffe HW, Valdiserri RO, De Cock KM. The reemerging HIV/AIDS epidemic in men who have sex with men. JAMA 2007; 298:2412-4.

33. Marks G, Crepaz N, Senterfitt JW, Janssen RS. Meta-analysis of high-risk sexual behavior in persons aware and unaware they are infected with HIV in the United States: implications for HIV prevention programs. J Acquir Immune Defic Syndr 2005; 39:446-53.

34. Pinho A. "Desafios na identificação e análise dos determinantes da epidemia": pesquisa RDS em homens que fazem sexo com homens. In: Anais do Seminário Estudos e Pesquisas em DST/HIV/AIDS: Determinantes Epidemiológicos e Sociocomportamentais. Rio de Janeiro: Associação Brasileira Interdisciplinar de Aids; 2009. p. 72. 


\section{Resumo}

Identificar os incentivos e as barreiras aos testes de HIV entre homens que fazem sexo com homens (HSH). Estudo transversal entre HSH que residiram pelo menos três meses na região metropolitana de Fortaleza, Ceará, Brasil, em 2010. Foram recrutados 391 homens, $\geq$ 18 anos, que relataram sexo com homens nos últimos seis meses, utilizando Respondent Driven Sampling. Coletados os dados: rede social, sociodemográficos e oferecido o teste de HIV e analisados pelo RDSAT $6.0 \mathrm{e}$ Stata 11.0. A maioria era jovem (40,3\%), de 5 a 11 anos de escolaridade (57,3\%), solteira (85,1\%), baixa renda (37,6\%), 58,1\% testaram para o HIV alguma vez na vida. Incentivos ao teste: certeza de não estar infectado (34,1\%) e campanha nacional Fique Sabendo (34\%). Barreiras: confiar no(s) parceiro(s) (21\%) e medo de discriminação se o resultado for positivo (20,3\%). Políticas que assegurem a confidencialidade dos testes e campanhas de comunicação voltadas às lacunas de informação e incentivo ao teste devem ser desenvolvidas.

HIV; Testes Anônimos; Homossexualidade Masculina; Comportamento Sexual

\section{Resumen}

Identificar los incentivos y las barreras a los test de VIH entre hombres que practican sexo con hombres (HSH). Estudio transversal entre HSH que residieron por lo menos tres meses en la región metropolitana de Fortaleza, Ceará, Brasil, en 2010. Fueron reclutados 391 hombres, $\geq 18$ años, que relataron sexo con hombres en los últimos seis meses, utilizando Respondent Driven Sampling. Datos recogidos: red social, sociodemográficos y ofrecido el test de VIH y analizados por el RDSAT 6.0 y Stata 11.0. La mayoría era joven (40,3\%), de 5 a 11 años de escolaridad (57,3\%), soltero (85,1\%), baja renta (37,6\%), 58,1\% se hicieron pruebas del VIH alguna vez en la vida. Incentivos al test: certeza de no estar infectado (34,1\%) y campaña nacional Fique Sabendo (34\%). Barreras: confiar en el compañero (s) (21\%) y miedo a la discriminación si el resultado fuera positivo (20,3\%). Se deben desarrollar politicas que aseguren la confidencialidad de los test, así como campañas de comunicación, dirigidas a las lagunas de información sobre este asunto, además de incentivos a la realización del test.

VIH; Pruebas Anónimas; Homosexualidad Masculina; Conducta Sexual
Submitted on 27/Mar/2015

Final version resubmitted on 14/Aug/2015

Approved on 28/Oct/2015 